\title{
Zaangażowanie parlamentów narodowych w latach 2015-2017 w działania na rzecz przezwyciężenia kryzysu imigracyjnego w UE
}

\begin{abstract}
Wstęp
Skutki kryzysu migracyjnego z lat 2015-2016 są odczuwalne w UE do tej pory. Konsekwencje bezprecedensowego napływu migrantów z Bliskiego Wschodu i Afryki Północnej sprzed trzech lat wymusiły głęboką reformę wewnątrz UE i wciąż rezonują wewnątrz państw członkowskich, zmieniając układ sił politycznych. Decyzje dotyczące zmian w polityce migracyjnej od 2015 r. podejmowane były przez instytucje unijne oraz rządy państw członkowskich. Niejednokrotnie odwoływano się przy tym do oczekiwań artykułowanych przez społeczeństwa. W całym procesie zmian polityki migracyjnej i reformy wspólnego europejskiego systemu azylowego mniej słyszalny był głos parlamentów narodowych, co nie znaczy że zabrakło zaangażowania politycznego tych instytucji.

Dialog z parlamentami narodowymi na temat rozwiązania sytuacji nielegalnej migracji w rejonie Morza Śródziemnego toczy się na forum COSAC (Konferencja Komisji do Spraw Unijnych Parlamentów UE) już od 2014 r. Zaangażowanie krajowych legislatur w tę dyskusję przybrało na sile przy okazji prac Komisji Europejskiej (KE) nad nowym programem w zakresie migracji i wraz z narastającym napływem nielegalnych migrantów w latach 2015 i 2016. Zwrócenie uwagi badawczej na parlamenty narodowe $\mathrm{w}$ tej sytuacji jest uzasadnione $\mathrm{z}$ dwóch powodów. Po pierwsze, kwestia migracyjna stała się jednym z najważniejszych tematów wewnętrznych dyskusji politycznych w poszczególnych państwach UE, wpływając na radykalizację nastrojów społecznych. W tym kontekście parlamenty są najważniejszym aktorem nadającym ton debacie krajowej. Po drugie, krajowe legislatury na poziomie unijnym powinny wspierać legitymizację decyzji podejmowanych na poziomie ponadnarodowym w UE.

Celem artykułu jest przedstawienie zaangażowania parlamentów państw członkowskich w działania na rzecz przezwyciężenia kryzysu migracyjnego w UE podejmowane w latach 2015-2017. Aby osiągnąć to założenie badawcze, należy odpowiedzieć na dwa pytania: po pierwsze, przy pomocy jakich narzędzi parlamenty narodowe włączyły się w działania UE mające rozwiązać kryzys migracyjny i po drugie, które z parlamentów narodowych państw członkowskich były najbardziej aktywne na forum unijnym w przedmiotowej sprawie? Odpowiedź na drugie z pytań pozwoli dodatkowo uzyskać informację, czy parlamenty narodowe państw negatywnie nastawionych do przyjmowania imigrantów były bardziej aktywne na forum UE niż parlamenty państw pozytywnie odnoszących się do tego zagadnienia?
\end{abstract}


Ukazanie stanu rzeczywistości społecznej w UE, którą stworzył kryzys migracyjny na podstawie obserwowalnych pojedynczych zjawisk pozwoli generalizować o ogólniejszych wnioskach dotyczących zaangażowania parlamentów krajowych w działania na rzecz przezwyciężenia kryzysu migracyjnego w UE. Zatem badanie empiryczne przedstawione $\mathrm{w}$ artykule ma charakter opisowy i pozwala na zastosowanie metody indukcyjnej. W artykule wykorzystana zostanie ponadto metoda analizy treści aktów legislacyjnych UE oraz dokumentów przesyłanych do instytucji unijnych przez parlamenty krajowe. Autor korzystał z raportów Komisji Europejskiej, Parlamentu Europejskiego oraz bazy IPEX. Jako uzupełniająca zastosowana zostanie także metoda statystyki deskryptywnej do pokazania aktywności parlamentów w mechanizmie kontroli przestrzegania zasady pomocniczości i dialogu politycznego.

W pierwszej części artykułu przedstawione zostaną uprawnienia parlamentów narodowych wynikające z prawa pierwotnego, dzięki którym instytucje te mogą w sposób podmiotowy wpływać na procesy polityczne w UE, w szczególności w ramach polityki migracyjnej, azylowej i kontroli granic. W drugiej części artykułu opisane zostaną działania, jakie parlamenty podejmowały w latach 2015-2017 wobec propozycji legislacyjnych KE dotyczących mechanizmu relokacji i przesiedleń oraz reformy wspólnego europejskiego systemu azylowego (WESA). Artykuł zakończą konkluzje odnoszące się do postawionych pytań badawczych.

\section{Uprawnienia przysługujące parlamentom narodowym $w$ ramach polityki migracyjnej, azylowej i kontroli granic UE}

Traktat lizboński znacznie umocnił rolę parlamentów narodowych w UE (Węc, 2011, s. 214-226). Największym novum w stosunku do wcześniejszych rozwiązań stanowiły uprawnienia wpływania na proces legislacyjny w UE poprzez tzw. mechanizm wczesnego ostrzegania. Dlatego w literaturze przedmiotu traktat lizboński określany jest jako „traktat parlamentów” (treaty of parliaments) (Haroche, 2018, s. 1010; Czachór, 2013, s. 13).

Przepisy odnoszące się do roli parlamentów narodowych są rozproszone zarówno w Traktacie o Unii Europejskiej (TUE), jak i Traktacie o funkcjonowaniu Unii Europejskiej (TFUE) (Pudło, 2014, s. 22-23; Węc, 2008, s. 197-206). Jednak dla określenia ram funkcjonowania parlamentów narodowych w UE zasadniczy jest art. 12 TUE (Traktat o Unii Europejskiej, s. 21). Wymienione jest w nim sześć obszarów, na których koncentruje się aktywność krajowych legislatur. Każdemu z nich przypisano szereg instrumentów, dzięki którym parlamenty mogą oddziaływać na proces decyzyjny i działania polityczne na szczeblu unijnym. W ramach czterech z obszarów wymienionych w art. 12 TUE krajowe legislatury mają do dyspozycji narzędzia proceduralne i instytucjonalne, które mogły wykorzystać w przypadku kryzysu migracyjnego. Po pierwsze, jest to otrzymywanie informacji od instytucji UE oraz projektów aktów ustawodawczych Unii, co określa Protokót $n r 1 \mathrm{w}$ sprawie roli parlamentów narodowych w UE dołączony do TUE, TFUE i Traktatu ustanawiającego Europejską Wspólnotę Energii Atomowej (Protokót $n r$ 1, s. 203-205). Po drugie, jest to kontrola przestrzegania zasady pomocniczości zgodnie z procedurami przewidzianymi w Protokole $n r 2$ 
w sprawie stosowania zasad pomocniczości i proporcjonalności dołączonym do TUE i TFUE (Protokół $n r$ 2, s. 206-209). Po trzecie, parlamenty uczestniczą w mechanizmach oceny polityk należących do przestrzeni wolności, bezpieczeństwa i sprawiedliwości. Aktywność parlamentów krajowych w tym zakresie sprowadza się do otrzymywania informacji o treści i wynikach wspomnianej oceny (art. 70 TFUE), udział w ocenie działalności Eurojustu (art. 85 ust. 1 TFUE) i w politycznej kontroli Europolu (art. 88 ust. 2 TFUE) (Traktat o funkcjonowaniu Unii Europejskiej, s. 74, 81-82, 84). Po czwarte, krajowe legislatury uczestniczą we współpracy między parlamentami narodowymi i z Parlamentem Europejskim (PE). Dodatkowo omówiony zostanie tak zwany dialog polityczny parlamentów z KE, jako piąty instrument przysługujący parlamentom na mocy już nie prawa pierwotnego i pochodnego, ale na mocy decyzji politycznej.

\subsection{Informowanie parlamentów narodowych w sprawach $U E$}

Zgodnie z przepisami traktatowymi w ramach tej procedury parlamenty krajowe otrzymują projekty dokumentów ustawodawczych i nieustawodawczych UE. W przypadku pierwszego typu dokumentów instytucjami uprawnionymi do przesyłania są KE, Rada Unii Europejskiej ${ }^{1}$ oraz PE, który przekazuje projekty aktów ustawodawczych, których jest autorem (Protokół $n r$ 1, art. 2).

Dokumenty nieustawodawcze, które otrzymują parlamenty od KE, to m.in. dokumenty konsultacyjne, komunikaty oraz roczny program prac legislacyjnych Komisji. Do tego typu dokumentów należą także porządki obrad Rady Unii Europejskiej, wyniki jej posiedzeń, w tym protokoły z posiedzeń, w czasie których rozpatrywano projekty aktów ustawodawczych. Protokót nr 1 w sprawie roli parlamentów narodowych w Unii Europejskiej wśród instytucji informujących legislatury krajowe wymienia także Radę Europejską oraz Trybunał Obrachunkowy (Protokół nr 1, art. 6 i 7). Pierwsza ze wspomnianych instytucji informuje parlamenty narodowe, gdy chce przyjąć na podstawie art. 48 ust. 7 akapit pierwszy lub drugi TUE decyzję umożliwiającą Radzie Unii Europejskiej głosowanie kwalifikowaną większością głosów w miejsce głosowania jednomyślnego (za wyjątkiem decyzji mających wpływ na kwestie wojskowe lub obronne) lub przyjmowania aktów prawnych zgodnie ze zwykłą procedurą ustawodawczą zamiast specjalnej procedury ustawodawczej.

Spośród wymienionych wyżej możliwości, dokumenty ustawodawcze i nieustawodawcze w latach 2015-2016 dotyczące polityki migracyjnej, azylowej i kontroli granic parlamentom narodowym przesyłała głównie KE.

\subsection{Kontrola przestrzegania zasady pomocniczości}

Kompetencje przyznane przez traktat lizboński parlamentom narodowym w zakresie kontroli przestrzegania zasady pomocniczości dają im możliwość bezpośredniego

${ }^{1}$ Dotyczy wniosków legislacyjnych pochodzących od grupy państw członkowskich, Trybunału Sprawiedliwości (TS UE), Europejskiego Banku Centralnego lub Europejskiego Banku Inwestycyjnego. 
oddziaływania na kształt aktów ustawodawczych. W Protokole $n r 2 w$ sprawie stosowania zasady pomocniczości i proporcjonalności owa kontrola podzielona jest na dwa etapy: ex ante oraz ex post. Pierwszy etap odnosi się do bezpośredniej kontroli aktu ustawodawczego na szczeblu unijnym, której dokonuje parlament narodowy (Proto$k o ́ t ~ n r 2$, art. 4-7). Kontrola ta obejmuje wszystkie projekty aktów ustawodawczych, a jej skutkiem może być zablokowanie procedury ustawodawczej. Drugi etap odbywa się przed TS UE i dotyczy obowiązujących już aktów, na które parlamenty narodowe mogą złożyć skargę o naruszenie zasady pomocniczości (Protokół $n r 2$, art. 8). Zatem kontrola ex post dotyczy tylko wybranych aktów ustawodawczych, a jej skutkiem może być delegalizacja danego aktu (Mik, 2010, s. 80-81).

$\mathrm{Z}$ punktu widzenia oceny zaangażowania parlamentów narodowych w kształtowanie działań UE dotyczących migracji, kontroli granic i polityki azylowej, istotne znaczenie ma wspomniany wcześniej pierwszy etap kontroli przestrzegania zasady subsydiarności. W ramach tzw. mechanizmu wczesnego ostrzegania (Early warning system) izby parlamentów państw członkowskich mają osiem tygodni na przesłanie przewodniczącym KE, Rady Unii Europejskiej i PE uzasadnionych opinii. Wskazane są w nich powody, dla których krajowa legislatura uznaje dany akt ustawodawczy za niezgodny z zasadą pomocniczości.

\subsection{Dialog polityczny}

Dialog polityczny z KE jest instrumentem wykorzystywanym przez parlamenty narodowe w UE, który w pewien sposób łączy dwie wcześniej omówione dziedziny, czyli informowanie w sprawach UE i kontrolę przestrzegania zasady subsydiarności. Jego specyfika wynika z faktu, że nie został on ustanowiony na mocy traktatów, ani aktów prawa wtórnego. Formuła dialogu politycznego została zainicjowana przez przewodniczącego KE José Manuela Barroso w 2006 r. KE miała bezpośrednio przesyłać do krajowych legislatur wszystkie nowe wnioski legislacyjne i dokumenty konsultacyjne (Komisja Europejska, COM (2006) 211, s. 9-10). Zapoczątkowało to pisemną wymianę poglądów między parlamentami krajowymi i KE dotyczącą wspomnianych dokumentów.

Wśród badaczy tego tematu nie ma zgody co do systemowej klasyfikacji dialogu politycznego. A. Pudło stosuje klasyfikację rozszerzającą (Pudło, 2014, s. 123-125). Według niej dialog polityczny z KE obejmuje nie tylko pisemną wymianę poglądów, ale także kontakty dwustronne na szczeblu administracyjnym lub politycznym poprzez wizyty członków KE w parlamentach krajowych lub poprzez przedstawicieli parlamentów ustanowionych do kontaktów w Brukseli. Klasyfikację zawężającą dialog polityczny do wzajemnej wymiany opinii i uwag odnośnie do dokumentów legislacyjnych i o innym charakterze stosują w swoich pracach m.in. M. Witkowska oraz autor niniejszego artykułu (Witkowska, 2016, s. 63-65; Dulak, 2017, s. 89, 294-299). Ujmowanie dialogu politycznego w ten sposób pozwala traktować go jako nieformalne uzupełnienie mechanizmu wczesnego ostrzegania, ale także, jako instrument wymuszający proaktywną postawę parlamentów i ich zaangażowanie w proces decyzyjny w UE. Przemawiają za tym następujące argumenty. Po pierwsze, większa ela- 
styczność dialogu politycznego dotycząca formy, jak i treści opinii, a także gwarancja otrzymania informacji zwrotnej, powodują, że parlamenty wykorzystują go częściej niż uzasadnione opinie. W latach 2010-2015 parlamenty przesłały do KE łącznie 2865 opinii w ramach dialogu politycznego, a jedynie 284 uzasadnionych opinii (Dulak, 2017, s. 294-303; Grzelak, Łacny, 2011, s. 32). Po drugie, parlamenty krajowe swoje uwagi i opinie dotyczące innych spraw niż kwestia zgodności z zasadą subsydiarności przesyłają także do PE. W przypadku PE opinie te nazywane są contributions i w oficjalnych dokumentach UE tłumaczone są jako tzw. przyczynki. Zarówno w przypadku KE, jak i PE wspomniane procedury zakładają przesłanie danej instytucji opinii do wybranego projektu aktu ustawodawczego, który zawiera poglądy izby dotyczące istotnych spraw politycznych, społecznych i gospodarczych, ale niepodnoszących kwestii zgodności z zasadą pomocniczości. Jedyna różnica między dialogiem politycznym a tzw. przyczynkami przesyłanymi do PE polega na tym, że w konsekwencji praktyki ukształtowanej w ramach inicjatywy Barroso z 2006 r. KE zobligowana jest do przesyłania odpowiedzi, a więc swoistego wejścia w dialog z parlamentami krajowymi nad sprawami legislacji unijnej. Trzecim argumentem przemawiającym za tym, aby w dialogu politycznym skupić się jedynie na jego aspekcie pisemnej wymiany poglądów z instytucjami UE jest właśnie wspomniana elastyczność tego instrumentu. Powoduje ona, że w UE dostrzeżono korzyści z ewentualnego wzmocnienia dialogu politycznego poprzez zezwolenie, aby w ramach opinii wysyłanych przez parlamenty narodowe istniała możliwość wnoszenia do KE propozycji inicjatyw ustawodawczych, w tym także przeglądu i uchylania istniejących przepisów (Borońska-Hryniewiecka, 2015, s. 1-2).

Z przytoczonych wyżej względów w dalszej części artykułu w ocenie zaangażowania legislatur krajowych w działania na rzecz rozwiązania problemów migracyjnych w UE wykorzystany zostanie także instrument dialogu politycznego z KE.

\subsection{Ocena i kontrola przestrzeni wolności, bezpieczeństwa i sprawiedliwości}

Na podstawie art. 70 TFUE państwa członkowskie mogą we współpracy z KE dokonywać oceny polityk unijnych realizowanych w ramach Tytułu V TFUE, czyli polityki kontroli granic, polityki azylowej, polityki migracyjnej, współpracy sądowej w sprawach cywilnych i karnych oraz współpracy policyjnej. Parlamenty narodowe oraz PE są informowane o treści i wynikach przeprowadzonej oceny. Z kolei na podstawie art. 71 TFUE parlamenty krajowe otrzymują informację o pracach Stałego Komitetu Współpracy Operacyjnej w Zakresie Bezpieczeństwa Wewnętrznego $^{2}$.

W ramach kompetencji dotyczących przestrzeni wolności, bezpieczeństwa i sprawiedliwości parlamenty narodowe mogą pełnić także rolę kontrolną. Dotyczy ona badania wniosków i inicjatyw ustawodawczych pod kątem przestrzegania zasady

${ }^{2}$ Działa on w ramach Rady Unii Europejskiej i jego zadaniem jest usprawnianie koordynacji państw członkowskich w zakresie działań operacyjnych dotyczących bezpieczeństwa wewnętrznego UE, w tym ścigania, kontroli granicznej i współpracy sądowej w sprawach karnych. 
pomocniczości, które odnoszą się do współpracy wymiarów sprawiedliwości państw członkowskich w sprawach karnych oraz współpracy policyjnej (art. 69 TFUE).

Ponadto parlamenty narodowe mogą uczestniczyć w ocenie Eurojustu, czyli agencji koordynującej współpracę między krajowymi organami śledczymi i organami ścigania dotyczącą poważnej przestępczości (art. 85 ust. 1 TFUE). Zadanie to ma istotne znaczenie w kontekście walki z przemytem nielegalnych imigrantów. Prace nad rozporządzeniem włączającym w praktyce parlamenty narodowe w ocenę Eurojustu rozpoczeły się w lipcu 2013 r., sam akt prawny został zaś przyjęty 14 listopada 2018 r. (Rozporządzenie 2018/1727, s. 138-183). W przepisach ustanawiających Agencję Unii Europejskiej ds. Współpracy Wymiarów Sprawiedliwości w Sprawach Karnych znalazły się także regulacje nadające uprawnienia parlamentom narodowym i PE. Zgodnie z nimi Eurojust przekazuje krajowym legislatywom sprawozdania roczne; wyniki badań i projektów strategicznych opracowanych lub zleconych przez Eurojust; dokument programowy zawierający założenia programu rocznego i wieloletniego; uzgodnienia robocze dokonane z osobami trzecimi. Co ciekawe, w pierwszej wersji projektu rozporządzenia rola parlamentów krajowych była słabsza względem PE, gdyż w przeciwieństwie do niego nie mogły one przedstawiać swoich uwag i wniosków do sprawozdania rocznego (Komisja Europejska, COM (2013) 535 final, art. 55).

Krajowe legislatury biorą także udział w kontroli innej agencji unijnej działającej w ramach współpracy policyjnej, czyli Europolu (art. 88 ust. 2 TFUE). Szczegółowe rozwiązania instytucjonalne i proceduralne $\mathrm{w}$ tej sprawie przyjęte zostały w rozporządzeniu PE i Rady z 11 maja 2016 r. w sprawie Agencji Unii Europejskiej ds. Współpracy Organów Ścigania (Europol) (Rozporzadzenie 2016/794, s. 53-114). Kontrola pod względem politycznym działań Europolu, które służą realizacji jego zadań odbywa się w ramach wyspecjalizowanej grupy ds. wspólnej kontroli parlamentarnej (GWKP). Tworzą ją wspólnie parlamenty narodowe i właściwa komisja PE. Do kompetencji GWKP należy: po pierwsze, wnioskowanie o spotkanie z przewodniczącym zarządu Europolu, dyrektorem wykonawczym lub ich zastępcami w celu omówienia działania agencji, jej struktury organizacyjnej, ustanowienia nowych jednostek i wyspecjalizowanych ośrodków, kwestii budżetowych; po drugie, zapraszanie na swoje posiedzenia innych odpowiednich osób, w tym co najmniej raz w roku Europejskiego Inspektora Danych Osobowych; po trzecie, konsultowanie wieloletniego programu działania Europolu. Na podstawie rozporządzenia GWKP uzyskała także prawo do otrzymywania od Europolu: ocen zagrożenia, analiz strategicznych, ogólnych sprawozdań sytuacyjnych, zleconych wyników badań, uzgodnień administracyjnych dotyczących przekazywania danych osobowych państwom trzecim i organizacjom międzynarodowym, rocznych i wieloletnich programów prac, rocznych sprawozdań nt. działalności Europolu, oraz sprawozdań z oceny Europolu sporządzonych przez KE (Rozporządzenia 2016/794, art. 51 ust. 3).

W maju 2016 r. w czasie spotkania Konferencji Przewodniczących Parlamentów Unii Europejskiej (KPPUE) powołano grupę roboczą, która do 16 grudnia $2016 \mathrm{r}$. miała przygotować projekt organizacji GWKP (Draft, s. 4-6). Założenia dotyczące tej kwestii oraz regulamin GWKP określono w czasie KPPUE w Bratysławie w dniach 23-24 kwietnia 2017 r. (Annex I, s. 5-6). Niecałe sześć miesięcy później, w dniach 
9-10 października, odbyło się spotkanie inaugurujące prace GWKP, zaś dokumenty statutowe grupy przyjęto dopiero w czasie prezydencji bułgarskiej 19 marca $2018 \mathrm{r}$. (Rules, s. 1-6). Zgodnie z regulaminem, spotkania GWKP odbywać się mają dwa razy w roku naprzemiennie w parlamencie państwa sprawującego prezydencję oraz w PE. Możliwe jest zorganizowanie spotkań nadzwyczajnych po spełnieniu określonych warunków. Każda z legislatur krajowych może być reprezentowana przez maksymalnie czterech parlamentarzystów, a w przypadku parlamentów dwuizbowych każda izba może nominować po dwóch członków do GWKP. PE może być reprezentowany przez maksymalnie szesnastu deputowanych. Nominowane osoby powinny być merytorycznie przygotowane do pracy w GWKP oraz gwarantować ciągłość jej funkcjonowania. W stosownych przypadkach, każdy parlament może powołać zastępców członków.

\subsection{Wspótpraca międzyparlamentarna w $U E$}

W literaturze przedmiotu wyróżnia się trzy główne rodzaje współpracy międzyparlamentarnej w sprawach UE (Pudło, 2014, s. 115). Pierwszy to współpraca parlamentów krajowych z instytucjami UE. Drugi rodzaj obejmuje współpracę między parlamentami państw członkowskich. Odbywa się ona w ramach Konferencji Komisji do Spraw Unijnych Parlamentów Unii Europejskiej (COSAC), Konferencji Przewodniczących Parlamentów Unii Europejskiej (KPPUE), IPEX - Międzyparlamentarnej Wymiany Informacji w sprawach UE. Trzeci rodzaj współpracy to współpraca o charakterze regionalnym, w ramach której odbywają się spotkania parlamentarzystów Grupy Wyszehradzkiej, Zgromadzenia Parlamentarnego Unii dla Śródziemnomorza, Zgromadzenia Parlamentarnego EURONEST oraz spotkania komisji parlamentarnych z Polski i państw Bałtyckich (Leksykon wielostronnej).

W dalszej części artykułu pod uwagę będą brane tylko niektóre ze wskazanych wyżej form współpracy, w ramach których w latach 2015-2017 omawiano działania dotyczące przeciwdziałania kryzysowi migracyjnemu. Pierwszą z nich będzie COSAC. W Protokole $n r 1 w$ sprawie roli parlamentów narodowych $w$ Unii Europejskiej wskazano, że COSAC ma wspierać wymianę informacji i najlepszych praktyk między PE i krajowymi legislaturami, w tym także między ich wyspecjalizowanymi komisjami (art. 10). Ponadto COSAC może także przedkładać PE, Radzie i KE wszystkie uwagi, które uzna za właściwe. Nie wprowadzono tu ograniczenia tematycznego. Zaznaczono jedynie, że współpraca między parlamentami w ramach COSAC odbywa się poprzez organizację konferencji międzyparlamentarnych na wybrane tematy, ze szczególnym wskazaniem na zagadnienia wspólnej polityki zagranicznej i bezpieczeństwa oraz wspólnej polityki bezpieczeństwa i obrony, a także organizowanie debat na temat prac $\mathrm{KE}$, jej strategii politycznej i programu prac legislacyjnych.

KPPUE, w skład której wchodzą przewodniczący parlamentów państw członkowskich UE i przewodniczący PE stanowi forum wymiany opinii, informacji i doświadczeń na temat aktywności parlamentów w UE. Spotkania tego gremium organizowane są raz w roku, w pierwszej połowie roku kalendarzowego, przez państwo sprawujące prezydencję w Radzie Unii Europejskiej. Ze względu na rangę polityczną i niewielką 
częstotliwość spotkań, sprawy podczas nich omawiane dotyczą kwestii istotnych dla bieżącego funkcjonowania UE, a decyzje podejmowane są przez konsensus ${ }^{3}$.

Instrumentami współpracy międzyparlamentarnej w UE, które mogą być wykorzystywane do zaangażowania się w zażegnanie kryzysu imigracyjnego są także Konferencja Międzyparlamentarna ds. wspólnej polityki zagranicznej i bezpieczeństwa/ wspólnej polityki bezpieczeństwa i obrony oraz wspólne spotkania komisji parlamentarnych. W pierwszym przypadku Konferencja, działająca na mocy art. 10 Protokołu nr 1, spotyka się dwa razy do roku w państwie sprawującym aktualnie prezydencję w Radzie Unii Europejskiej. Uczestniczą w niej sześcioosobowe delegacje poszczególnych parlamentów narodowych państw członkowskich UE oraz szesnastoosobowa delegacja PE. Na Konferencje zapraszany jest także Wysoki Przedstawiciel Unii ds. Zagranicznych i Polityki Bezpieczeństwa. W spotkaniach mogą uczestniczyć również czteroosobowe delegacje obserwatorów z parlamentów państw kandydujących do członkostwa oraz każdego europejskiego państwa członkowskiego NATO. Konferencja Międzyparlamentarna jest okazją do wymiany informacji i doświadczeń w kwestiach europejskiej polityki zagranicznej i polityki bezpieczeństwa, co sprzyja kontroli parlamentarnej nad działaniami rządów w tych kwestiach (Pudło, 2014, s. 123).

Wspólne spotkania komisji PE i parlamentów krajowych organizowane są z inicjatywy komisji sektorowych pierwszej ze wspomnianych instytucji. Mogą one mieć formułę spotkań przewodniczących komisji lub międzyparlamentarnych spotkań całych komisji. Omawiane są wówczas konkretne zagadnienia wchodzące w zakres merytoryczny prac komisji, w tym także aktualne wnioski legislacyjne KE. Łącznie tego typu spotkań odbywa się w ciągu roku kilkanaście (Relations with national).

\section{Zaangażowanie parlamentów narodowych w działania UE dotyczące zmian w polityce migracyjnej i reformy wspólnego europejskiego systemu azylowego}

Analizowany okres obejmuje wydarzenia mające miejsce od początku 2015 do połowy 2017 roku. W tym czasie państwa członkowskie UE zostały poddane niespotykanej dotąd presji migracyjnej. Urząd Wysokiego Komisarza Narodów Zjednoczonych do spraw Uchodźców podaje, że od stycznia 2015 do czerwca 2017 r. do południowych granic UE przybyło 1479242 uchodźców z Syrii, Iraku oraz krajów Afryki Północnej (UNHCR Operational). W szczytowym okresie wzbierania fali migracyjnej, czyli od maja do października 2015 r. do UE przybyło 688910 osób. Duży napływ imigrantów spowodował w tym czasie przeciążenie unijnego systemu migracyjnego. Według Eurostatu w 2015 r. 1322845 osób złożyło wnioski o azyl, z czego 80\% przypadło na sześć państw członkowskich - Niemcy, Węgry, Szwecję, Austrię, Włochy i Francję (Eurostat, Asylum; Węc, 2017, s. 7-11; Adamyczk, 2016, s. 41-45). Zmusiło to UE do podjęcia nadzwyczajnych działań w ramach polityki migracyjnej, polityki azylowej i kontroli granic. Do najważniejszych inicjatyw podjętych w latach 2015-2017, które będą stanowiły przedmiot dalszej analizy, należą: po pierwsze, opublikowanie 13 maja

${ }^{3}$ Są to m.in. kwestie związane ze wspólną polityką zagraniczną i bezpieczeństwa, wspólną polityką bezpieczeństwa i obrony, przestrzenią wolności, bezpieczeństwa i sprawiedliwości, problemy kryzysu finansowego i stabilności strefy euro. 
2015 r. przez KE komunikatu zatytułowanego „Europejski program w zakresie migracji”; po drugie, przyjęcie pierwszego (27 maja 2015 r.) i drugiego (9 września 2015 r.) pakietu wdrożeniowego do „Europejskiego programu w zakresie migracji”; po trzecie, podpisanie 18 marca 2016 r. umowy między UE i Turcją w sprawie zwalczania kryzysu migracyjnego; po czwarte, przedstawienie przez KE 4 maja i 13 lipca 2016 r. pakietu siedmiu projektów aktów prawnych reformujących WESA (Węc, 2017, s. 11-39; Adamczyk, 2016, s. 47-61).

Spośród narzędzi wymienionych w pierwszej części artykułu, które pozostawały do dyspozycji parlamentów w sprawach związanych z kryzysem migracyjnym nie wykorzystano w ogóle instrumentów oceny i kontroli przestrzeni wolności, bezpieczeństwa i sprawiedliwości. W analizowanym okresie brak było bowiem odpowiednich regulacji wykonawczych pozwalających w ramach GWKP zapoznać się z ocenami zagrożeń, sprawozdaniami sytuacyjnymi oraz analizami Europolu na temat ochrony granic zewnętrznych i walki z grupami przestępczymi zajmującymi się przemytem migrantów.

\subsection{Wspótpraca międzyparlamentarna}

W czasie spotkania KPPUE w Rzymie w dniach 20-21 kwietnia 2015 r., a więc na niecały miesiąc przed opublikowaniem przez KE komunikatu Europejski program $w$ zakresie migracji, przewodniczący izb parlamentarnych wyrazili oczekiwanie, że ów dokument powinien opierać się na czterech priorytetach: konsolidacji wspólnego systemu azylowego, aktualizacji europejskiej polityki dotyczącej legalnej imigracji, zwiększenia wysiłków na rzecz zwalczania nielegalnej imigracji i handlu ludźmi, a także wprowadzeniu silniejszych środków kontroli granic zewnętrznych. W ślad za tym przewodniczący parlamentów oczekiwali wzmocnienia zdolności i zwiększenia finansowania Frontexu w celu zapobiegania napływowi imigrantów przez Morze Śródziemne oraz ze wschodu do strefy Schengen. Wyrażono także żądanie skierowane do KE, aby w opracowywaniu rozwiązań kierowała się ona zasadami solidarności w podziale obowiązków między państwa członkowskie (Conference of the Speakers of the EU Parliaments, 2015, s. 3-4). Jasne i precyzyjne sformułowanie oczekiwań wobec KE świadczyło, że już wiosną 2015 r. przewodniczący parlamentów krajowych zdawali sobie sprawę z zagrożeń, jakie niosła dla UE i ochrony jej granic wzbierająca fala migracyjna.

W czasie kolejnego posiedzenia KPPUE w Luksemburgu w dniach 22-24 maja 2016 r. temat kryzysu migracyjnego i działań UE w celu jego zażegnania zdominował rozmowy przewodniczących krajowych legislatur. Parlamenty skupiły się na humanitarnej stronie kryzysu migracyjnego, wzywając do zdecydowanego zwalczania przemytników i handlarzy ludźmi, a także niestygmatyzowania legalnych imigrantów i traktowania ich w sposób ludzki i godny. Postulowano także, aby jak najszybciej przyjąć wspólną europejską listę bezpiecznych państw pochodzenia, która umożliwi szybką repatriację osób niemających prawa do ochrony międzynarodowej. Spotkanie przewodniczących w Luksemburgu odbyło się niecały rok po przyjęciu decyzji Rady Unii Europejskiej ws. relokacji i przesiedleń oraz dwa miesiące po podpisaniu umo- 
wy z Turcją. Dlatego też w konkluzjach możemy znaleźć żądania wzmocnienia „[...] czynnej i biernej solidarności oraz odpowiedzialności wewnątrz Unii" (Conference of Speakers of the EU Parliaments, 2016, s. 3) w działaniach wdrażających decyzje Rady oraz żądania dokonania ,[...] szybkiego postępu w kierunku systemu azylowego prawdziwie wspólnego pod względem podziału odpowiedzialności i solidarności” (ibidem, s. 4). Do tych dwóch punktów konkluzji ze spotkania zastrzeżenia złożyło sześć izb parlamentów państw członkowskich. Były to: słowacka Národná Rada, polski Sejm i Senat, czeskie Poslanecká sněmovna i Senát oraz węgierski Országgyülés. Nie zgadzały się one szczególnie z utworzeniem systemu azylowego wspólnego pod względem odpowiedzialności i solidarności, rozumiejąc pod tymi pojęciami brak możliwość podejmowania suwerennych decyzji dotyczących sposobów udziału w działaniach relokacji i przesiedleń. Izby te zaznaczyły wówczas, że pod pojęciem przyspieszenia relokacji rozumieją one prowadzenie niezbędnych kontroli bezpieczeństwa. Parlamenty te nie sprzeciwiły się natomiast ostatecznej konkluzji z KPPUE mówiącej o tym, że „,...] koniecznemu wzmocnieniu kontroli granic zewnętrznych Unii Europejskiej powinna towarzyszyć intensyfikacja wsparcia dla uchodźców syryjskich, państw sąsiadujących z Syrią, jak również państw członkowskich najbardziej dotkniętych przez ten kryzys" (ibidem, s. 5).

Drugie spotkanie KPPUE pokazało, że różnice zdań między państwami członkowskimi w odniesieniu do mechanizmu relokacji i przesiedleń zaproponowanego przez KE w maju i wrześniu 2015 r. widoczne są także na parlamentarnym poziomie systemu politycznego UE. Posiedzenie w Luksemburgu dowiodło także, że państwa członkowskie, głównie z Europy Środkowo-Wschodniej, oprócz spotkań Rady Unii Europejskiej i szczytów szefów państw lub rządów wykorzystywały również inne instrumenty polityczne do prezentowania swojego stanowiska w sprawach kluczowych dla ich interesu narodowego.

Podobną dynamikę kształtowania się stanowiska parlamentów narodowych, jaka ujawniła się w czasie posiedzeń KPPUE, można było zaobserwować w czasie spotkań Międzyparlamentarnej Konferencji ds. WPZiB/WPBiO. Już w czasie obrad w Rydze (2-6 marca 2015 r.) dostrzeżono narastające przepływy migracyjne przez basen Morza Śródziemnego, które generowały zagrożenie dla granic zewnętrznych UE. Wezwano wówczas do szybszej reakcji i lepiej skoordynowanego zarządzana przepływami migracyjnymi (Konferencja, 2015a, s. 2-3). Podczas kolejnego spotkania Konferencji w Luksemburgu na początku września 2015 r., a więc w momencie największego napływu migrantów do UE, nastąpiła konkretyzacja stanowisk przedstawicieli parlamentów krajowych i PE (Konferencja, 2015b, s. 5-8). Wezwano do zapewnienia schronienia uchodźcom na terenie państw członkowskich oraz walki z przemytnikami. Wyrażono oczekiwania wzmocnienia współpracy UE z krajami pochodzenia i tranzytu. Wskazano szczególnie na współpracę z Turcją jako znaczącym krajem tranzytowym, także ze względu na sytuację w Syrii i Iraku. Wnioskowano o większe środki na tworzenie programów rozwoju w regionie Afryki Północnej i Półwyspu Somalijskiego, gdyż jak podkreślano, stabilizacja w rejonie Bliskiego Wschodu oraz Afryki Północnej ma kluczowe znaczenie dla zmniejszenia napływu migrantów do UE. W odniesieniu do tymczasowego mechanizmu relokacji i przesiedleń przyjętego w czerwcu 2015 r. wezwano do okazywania solidarności „,[...] zarówno wobec państw członkowskich, w których 
presja migracyjna jest najsilniejsza, jak też w stosunku do osób przybywających do UE w poszukiwaniu azylu" (ibidem). W czasie kolejnego spotkania Konferencji w Hadze w dniu 8 kwietnia 2016 r. przyjęte konkluzje zawierały podobne postulaty, jak te z Luksemburga (Konferencja, 2016a, s. 4-6). Zmiana akcentów w stanowiskach parlamentów jest widoczna dopiero w konkluzjach ze spotkania w Bratysławie (2-4 września 2016 r.). Migrację określono w nich jako zjawisko globalne, dlatego bardziej niż na tymczasowych rozwiązaniach UE powinna skoncentrować się na wypracowaniu kompleksowego podejścia do problemu migracji i połączenia go ze zrównoważonym rozwojem. Pod tym hasłem rozumiano eliminowanie przyczyn masowych migracji, takich jak ubóstwo i konflikty zbrojne. Wiązać miałoby się to ze zwiększeniem finansowania UE dla Afryki oraz gruntownym przeglądem istniejących polityk w zakresie handlu, rolnictwa, rybołówstwa i innych obszarów, które mają bezpośredni wpływ na ten kontynent, a także skoordynowania działań międzynarodowych na poziomie ONZ (Konferencja, 2016b, s. 6-7). W czasie spotkania przedstawicieli parlamentów krajowych i PE na Malcie w dniach 26-28 kwietnia 2017 r. jeszcze raz podkreślono potrzebę wspólnych działań wszystkich państw członkowskich w kwestii uchodźców. W konkluzjach zauważono konieczność ,[...] ustanowienia prawdziwej, opartej na wartościach, wspólnej europejskiej polityki migracyjnej w oparciu o zasadę solidarności i współdzielonej odpowiedzialności z zabezpieczeniem granic zewnętrznych UE" (Konferencja, 2017, s. 7). Wyrażono także oczekiwanie wobec KE dotyczące ,,[...] przeglądu istniejącego systemu azylowego (Dublin III) i odpowiednich legalnych kanałów umożliwiających bezpieczną i uporządkowaną migrację, jako zrównoważonej długookresowej polityki mającej na celu wspieranie wzrostu i spójności w UE, w celu ustanowienia wyraźnych ram dla stosunków UE z krajami trzecimi” (ibidem). W czasie Konferencji podkreślono, że ,[...] należy wzmacniać związek pomiędzy polityką migracyjną a polityką rozwojową i prowadzić rzeczywistą i naprawdę efektywną współpracę, bez uzależniania pomocy rozwojowej od współpracy w kwestiach migracji, takich jak zarządzanie granicami i umowy o readmisji” (ibidem).

Podziały między państwami członkowskimi na tle zaproponowanych przez KE mechanizmów przeciwdziałania nielegalnej migracji uwidoczniły się wyraźniej podczas cyklicznego badania opinii i stanowisk parlamentów w ramach COSAC. Pod koniec 2015 r. szesnaście izb parlamentarnych zaprezentowało swoje poglądy na temat środków podjętych przez KE w zakresie polityki migracyjnej i azylowej. Negatywne stanowisko wyraziły polski Sejm i Senat, węgierski Országgyülés, estoński Riigikogu, czeskie Poslanecká sněmovna i Senát, litewski Seimas, łotewska Saeima, słowacka Národná Rada, austriacka Nationalrat i brytyjska House of Lords (Dwudziesty, s. 17-26). Wszystkie z wymienionych izb opowiedziały się za rozmieszczaniem uchodźców na zasadzie dobrowolności. Dodatkowo sprzeciwiły się one (oprócz House of Lords) tzw. kwotom imigracyjnym określonym przez KE dla państw członkowskich i uznały, że KE powinna utworzyć rozsądny systemu podziału oparty na faktycznych możliwościach państw. Ponadto Riigikogu zaznaczył w swojej odpowiedzi do COSAC, że państwa członkowskie powinny jednogłośnie decydować o metodzie podziału migrantów w ramach systemu relokacji. Metoda powinna brać pod uwagę liczbę ludności oraz rozmiar gospodarki danego państwa w proporcji do UE. Polski Sejm zaznaczył, że KE powinna uwzględnić sytuację na Ukrainie, gdyż w obliczu napływu uchodźców 
z tego kraju Polska stała się także krajem docelowym dla imigrantów. Pięć izb parlamentów krajowych w ankiecie COSAC poparło propozycję KE dotyczącą systemu podziału uchodźców z maja i września 2015 r. Były to portugalska Assembleia da República, włoskie Camera dei deputati i Senato della Repubblica, niemiecki Bundesrat i holenderska Tweede Kamer. Pierwsza ze wymienionych izb stwierdziła, że wszystkie państwa powinny włączyć się w mechanizm, ale KE powinna przydzielić środki finansowe tym krajom, które mają trudności z adaptacją do wymogów systemu azylowego. Izba niższa holenderskiego parlamentu wyraziła w swojej opinii poparcie dla relokacji i przesiedleń w perspektywie krótkoterminowej. W dłuższym terminie należałoby jednak według niej poprawić proces przyjmowania uchodźców na szczeblu regionalnym.

W ankiecie COSAC parlamenty wskazywały, że w czasie wewnętrznych dyskusji nad Europejskim programem w zakresie migracji pojawiły się nowe propozycje, które mogłyby zostać wykorzystane przez KE (ibidem, s. 18-20). Włoska Camera dei deputati postulowała przeniesienie siedziby Frontexu bliżej środkowej części Morza Śródziemnego. Inne parlamenty państw południowej Europy również proponowały rozwiązania, które bezpośrednio wpłynęłyby na ich bezpieczeństwo. Maltańska Kamra tad-Deputati postulowała, aby UE w bardziej ustrukturyzowany sposób wspierała działania stabilizujące sytuację w Libii. Wsparcie dla afrykańskich służb zajmujących się pomocą ludności postulowała także holenderska Tweede Kamer. Zaś portugalska Assembleia da República postulowała utworzenie punktów informacyjnych w państwach pochodzenia, państwach tranzytu i państwach docelowych w celu przekazywania migrantom informacji oraz wytycznych na temat ich praw i obowiązków. Zapewnienie obywatelom państw trzecich pełnej informacji o ryzyku nielegalnej migracji postulowały także litewski Seimas oraz słowacka Národná Rada. Na konieczność podjęcia pilnych działań ratujących życie na morzu wskazywał szwedzki Riksdag, a portugalski parlament postulował dodatkowo, aby w misje ratunkowe na Morzu Śródziemnym zaangażować prywatnych operatorów, np. marynarki handlowe i zapewnić im odszkodowania jako zachętę do współpracy. Parlament Słowacji zaproponował, aby tworzyć strefy bezpieczeństwa w państwach pochodzenia oraz przeprowadzać procedury azylowe poza terytorium UE w państwach pochodzenia lub tranzytowych. Działania te powinny iść $\mathrm{w}$ parze ze wzmocnieniem granic zewnętrznych szczególnie w celu ograniczenia napływu imigrantów przez szlak zachodniobałkański, co postulował węgierski Országgyülés.

Ostatnim wydarzeniem w ramach współpracy międzyparlamentarnej, w czasie którego przedstawiciele parlamentów prezentowali swoje stanowiska odnośnie do reformy WESA było międzyparlamentarne spotkanie komisji PE i parlamentów krajowych w dniu 28 lutego 2017 r. Na zaproszenie komisje LIBE (wolności obywatelskie, sprawiedliwość i sprawy wewnętrzne) zorganizowano dyskusję pt. Trzecia reforma wspólnego europejskiego systemu azylowego - gotowi na wyzwanie (The Third Reform). Parlamentarzyści z państw członkowskich wykorzystali to spotkanie do zaprezentowania stanowisk krajowych w kwestii mechanizmów relokacji i przesiedleń, a także ogólnych zasad, na podstawie których powinien działać WESA. Powtórzono poglądy, które parlamenty przedstawiły w kwestionariuszu COSAC przywołanym wyżej. Pojawiły się jednak odniesienia do propozycji KE z maja i lipca 2016 r. dotyczące projek- 
tów aktów legislacyjnych reformujących WESA. Przedstawiciel rumuńskiego Senatu wskazywał na konieczność rozróżnienia przez system osób, które realnie potrzebują ochrony międzynarodowej od tych, które są migrantami ekonomicznymi. Reprezentant fińskiej Eduskunty zauważył, że uchodźcy napływający do UE są w większości migrantami ekonomicznymi, dlatego Unia w pierwszej kolejność powinna działać na rzecz poprawy warunków życia w krajach pochodzenia. Delegacja parlamentu brytyjskiego zwróciła uwagę na wzmocnienie opieki małoletnich uchodźców (unccompanied minors), którzy stają się celem zorganizowanych grup przestępczych. Zaś parlamentarzyści ze szwedzkiego Riksdagu podkreślili, że UE nie powinna zmuszać państw, których społeczeństwa nie są przygotowane na przyjęcie uchodźców. W zamian za to UE powinna wspierać te kraje, które są najbardziej narażone na napływ migrantów także, w wyniku ruchów wtórnych (secondary movements). Jednoznaczne wypowiedzi krajowych parlamentarzystów wskazują, że międzyparlamentarne spotkanie komisji zostało potraktowane jako jeszcze jedna okazja do przedstawienia przed przedstawicielami PE i KE stanowisk rządów państw członkowskich w kwestii zmian w polityce migracyjnej i azylowej UE.

\subsection{Informowanie parlamentów w sprawach UE, kontrola przestrzegania zasady subsydiarności $i$ dialog polityczny}

Ostatnie trzy instrumenty, które wykorzystywały parlamenty krajowe w celu wpływania na kształt rozwiązań prawnych UE dotyczących kryzysu migracyjnego to otrzymywanie dokumentów legislacyjnych i nielegislacyjnych od instytucji UE, wyrażanie uzasadnionych opinii do projektów aktów ustawodawczych oraz przesyłanie opinii do instytucji unijnych $\mathrm{w}$ ramach dialogu politycznego. Wspomniane instrumenty zostały ujęte w jednym rozdziale, gdyż ich wykorzystanie uzależnione jest od otrzymania przez parlamenty stosownych dokumentów UE.

W dalszej części artykułu poddanych analizie zostanie łącznie czternaście dokumentów legislacyjnych i nielegislacyjnych UE, którymi zajmowały się parlamenty krajowe od początku 2015 do połowy 2017 r. Podzielone zostały one na dwie grupy. Pierwsza z nich dotyczy funkcjonowania mechanizmów relokacji i przesiedleń. Należą do niej: komunikat KE dotyczący Europejskiego program w zakresie migracji z 13 maja 2015 r. (Komisja Europejska, COM (2015) 240), projekt decyzji Rady wprowadzający środki przejściowe na korzyść Włoch i Grecji z 27 maja 2015 r. (Komisja Europejska, COM (2015) 286), projekt rozporządzenia ustanawiającego kryzysowy mechanizm relokacji z 9 września 2015 r. (Komisja Europejska, COM (2015) 450), projekt decyzji Rady wprowadzający środki tymczasowe na rzecz Włoch, Grecji i Węgier z 9 września 2015 r. (Komisja Europejska, COM (2015) 451), projekt rozporządzenia określający wykaz bezpiecznych krajów pochodzenia z 9 września 2015 r. (Komisja Europejska, COM (2015) 452), komunikat KE dotyczący planu działania UE w zakresie powrotów z 9 września 2015 r. (Komisja Europejska, COM (2015) 453).

Druga grupa dokumentów obejmuje akty prawne składające się na pakiet reformujący wspólny europejski system azylowy: projekt rozporządzenia z 4 maja 2016 r. zmieniającego rozporządzenie Dublin III (Komisja Europejska, COM (2016) 270), 
projekt rozporządzenia w sprawie Agencji Unii Europejskiej ds. Azylu z 4 maja 2016 r. (Komisja Europejska, COM (2016) 271), projekt rozporządzenia w sprawie systemu EURODAC z 4 maja 2016 r. (Komisja Europejska, COM (2016) 272), projekt dyrektywy z 13 lipca 2016 r. zmieniający tzw. dyrektywę recepcyjną (Komisja Europejska, COM (2016) 465), projekt rozporządzenia z 13 lipca 2016 r. zmieniający dyrektywę kwalifikacyjną (Komisja Europejska, COM (2016) 466), projekt rozporządzenia z 13 lipca 2016 r. zmieniający dyrektywę azylową (Komisja Europejska, COM (2016) 467), projekt rozporządzenia w sprawie unijnych ram przesiedleń z 13 lipca $2016 \mathrm{r}$. (Komisja Europejska, COM (2016) 468).

Dodatkowo w analizie uwzględniony zostanie także Komunikat Komisji do Parlamentu Europejskiego i Rady. W Kierunku Reformy Wspólnego Europejskiego Systemu Azylowego i Zwiększenia Liczby Legalnych Sposobów Migracji do Europy z 6 kwietnia 2016 r. (Komisja Europejska, COM (2016) 197), określający pięć kierunków reformy WESA, które zostały później ujęte w pakiecie legislacyjnym z maja i lipca tegoż roku.

Wśród parlamentów narodowych najwięcej zastrzeżeń dotyczących zgodności z zasadą pomocniczości padało wobec wniosku KE z 9 września 2015 r. ustanawiającego kryzysowy mechanizm relokacji oraz wniosku KE z 4 maja 2016 r. zmieniającego rozporządzenie Dublin III i wprowadzający tzw. korekcyjny mechanizm przydziału migrantów, który miał być uruchamiany automatycznie w sytuacji kryzysowej (Komisja Europejska, COM (2016) 469 final; idem, COM (2016) 471 final; idem, (2017) 600 final; idem, COM (2017) 601 final). W pierwszym przypadku parlamenty krajowe zgłosiły pięć uzasadnionych opinii ${ }^{4}$, w drugim przypadku osiem ${ }^{5}$. Włoska izba wyższa - Senato della Republica - złożyła także jedną uzasadnioną opinię do wniosku KE z 13 lipca 2016 r. dotyczącego zmiany tzw. dyrektywy recepcyjnej, która ujednolicała warunki przyjmowania migrantów oraz ograniczała wtórne przepływy.

W przypadku pierwszego ze wskazanych projektów aktu ustawodawczego, do którego zgłoszono uzasadnione opinie, najwięcej zastrzeżeń dotyczyło podstawy prawnej. Zdaniem wszystkich wymienionych izb parlamentarnych art. 78 ust. 3 TFUE nie daje KE możliwości ustanawiania stałego mechanizmu relokacji (Reasoned opinions on COM/2015/0450; European Parliament). Zdaniem obu izb czeskiego parlamentu stały mechanizm przekazuje KE uprawnienia, które mają znaczący wpływ na systemy azylowe państw członkowskich i silnie oddziałują na ich polityki wewnętrzne. Parlament węgierski podkreślał, że KE tworzy zautomatyzowany i scentralizowany mechanizm, który nie został poddany wystarczającym konsultacjom z państwami członkowskimi oraz został stworzony bez aktywnego udziały Rady Unii Europejskiej. Izba niższa parlamentu rumuńskiego w nieco bardziej wyważonym tonie wskazywała, że tworzenie stałego mechanizmu na podstawie art. 78 ust. 3 nie jest potrzebne, a opracowany przez KE klucz dystrybucji migrantów między państwami powinien brać dokładniej pod uwagę krajowe uwarunkowania. Z kolei słowacki parlament uznał w swojej uzasadnionej opinii, że propozycja KE wprowadza stałą derogację od przepisów tzw. rozpo-

${ }^{4}$ Czeskie Poslanecká sněmovna i Sénat, węgierski Országgyülés, rumuńska Camera Deputaților oraz słowacka Národná Rada.

${ }^{5}$ Czeskie Poslanecká snèmovna i Sénat, węgierski Országgyülés, rumuńska Camera Deputaților, słowacka Národná Rada, polski Sejm i Senat oraz włoski Senato della Republica. 
rządzenia dublińskiego, które zobowiązuje państwa członkowskie do analizy przesłanek nadania międzynarodowej ochrony prawnej imigrantowi. Stąd cele wniosku mogą być lepiej osiągnięte na poziomie krajowym, niż na poziomie UE.

Argumenty parlamentów zawarte w uzasadnionych opiniach dotyczących wniosku KE z 4 maja 2016 r., który zmieniał rozporządzenie Dublin III i który ustanawiał tzw. korekcyjny mechanizm przydziału, czyli bardziej restrykcyjny instrument względem kryzysowego mechanizmu relokacji z 9 września 2015 r., brzmiały podobnie (Reasoned opinions on COM/2016/0270; European Parliament). Węgierski Országgyülés stwierdzał, że propozycja KE wykracza poza uprawnienia nadane jej w traktatach, a konkretnie w art. 78 ust. 2e TFUE. Czeskie Poslanecká sněmovna i Sénat wskazywały, że korekcyjny mechanizm przydziału nie bierze pod uwagę aktualnej sytuacji w państwach członkowskich oraz ich zdolności infrastrukturalnych do przyjmowania uchodźców. W opinii stwierdzono, że przymusowo relokowani uchodźcy nie będą mieli motywacji do zintegrowania się ze społeczeństwem kraju przyjmującego, do którego zostali wysłani. Zauważono, że kary dla państwa za nie przyjmowanie uchodźców, które przewidywał projekt rozporządzenia, mogą doprowadzić do ich skumulowania w przypadku, gdy system weryfikował będzie osoby, które nie mogą uzyskać ochrony międzynarodowej, ale też nie mogą zostać odesłane do kraju trzeciego. Czeski parlament w swojej opinii wyraził także brak zgody na rozszerzenie uprawnień EASO tak, aby z własnej inicjatywy ingerowała w kompetencje państw dotyczące przyznawania ochrony międzynarodowej. Zbliżone argumenty w odniesieniu do kar finansowych przywoływała także rumuńska izba niższa - Camera Deputaţilor. Słowacka Národná Rada zauważyła, że dotychczasowa praktyka narzucania limitów przyjmowania uchodźców nie była skuteczna, dlatego uznała korekcyjny mechanizm przydziału za niewykonywalny, zaś tzw. wkład solidarnościowy, czyli kary finansowe, za niezgodny z zasadą proporcjonalności.

Do głosów krytycznych wobec propozycji legislacyjnej KE zmieniającej rozporządzenie Dublin III dołączył polski parlament (ibidem). Jego obie izby w swojej opinii wskazały, że korekcyjny mechanizm przydziału jest niezgodny z zasadą pomocniczości. Zdaniem Sejmu i Senatu rozwiązanie to wkracza zbyt głęboko w zastrzeżone kompetencje państw dotyczące polityki bezpieczeństwa i praw socjalnych, a ostatecznie mechanizm korekcyjny może doprowadzić do „,przerzucania” azylantów do odleglejszych państw członkowskich. Automatyczny algorytm podziału migrantów między państwa według Sejmu i Senatu (tzw. klucz odniesienia) nie uwzględnia wsparcia udzielanego innym państwom, posiadania granicy zewnętrznej UE oraz zdolności recepcyjnych i integracyjnych. Skrytykowano także, zbyt wysokiego tzw. wkładu solidarnościowego.

Włoski Senato della Repubblica w uzasadnionej opinii wobec omawianego projektu rozporządzenia KE krytykowały tę propozycję, zarzucając jej jednak zbytnią łagodność (ibidem). Izba wyższa włoskiego parlamentu podkreśliła, że powstrzymanie niekontrolowanej migracji może nastąpić tylko poprzez wspólne unijne działania, ale zaproponowane przepisy nie idą w tym kierunku. Skrytykowano propozycję, że wstępna ocena wniosków azylowych zanim uruchomione zostaną procedury dublińskie może spowodować, że kraje pierwszego wjazdu (takie jak np. Włochy) nie poradzą sobie z analizą coraz większej liczby spraw. Zaproponowano, aby próg urucho- 
mienia korekcyjnego mechanizmu przydziału był niższy, a kary pieniężne nałożone na państwa członkowskie odmawiające przyjmowania imigrantów powinny być wyższe niż proponowane 250 tys. euro za osobę.

Wśród parlamentów krajowych najwięcej opinii w ramach dialogu politycznego z KE oraz opinii wysyłanych do PE (tzw. contributions) wysłała rumuńska Camera Deputaților (tabela 1). Najwięcej zaś opinii ogólnie parlamenty zgłaszały do projektów legislacyjnych reformujących WESA, szczególnie projektu rozporządzenia w sprawie Agencji Unii Europejskiej ds. Azylu z 4 maja 2016 r. (po 8 opinii przesłanych do KE i PE) oraz projektu rozporządzenia kwalifikacyjnego z 13 lipca 2016 r. (po 7 opinii przesłanych do KE i PE).

Tabela 1

Liczba opinii parlamentów narodowych przesłanych do KE w ramach dialogu politycznego oraz do PE, jako tzw. contributions, dotyczących aktów ustawodawczych i nieustawodawczych $\mathrm{z}$ lat 2015-2016 i mających na celu zażegnanie kryzysu migracyjnego w UE

\begin{tabular}{||l|c|c|c|c|c|c||}
\hline \multirow{2}{*}{} & \multicolumn{2}{|c|}{$\begin{array}{c}\text { Dialog polityczny } \\
\text { (KE) }\end{array}$} & \multicolumn{2}{c|}{ Contributions (PE) } & \multicolumn{2}{c||}{ Suma } \\
\cline { 2 - 7 } & $\begin{array}{c}\text { relokacja } \\
\text { i przesie- } \\
\text { dlenia }\end{array}$ & $\begin{array}{c}\text { reforma } \\
\text { WESA }\end{array}$ & $\begin{array}{c}\text { relokacja } \\
\text { i przesie- } \\
\text { dlenia }\end{array}$ & $\begin{array}{c}\text { reforma } \\
\text { WESA }\end{array}$ & $\begin{array}{c}\text { relokacja } \\
\text { i przesie- } \\
\text { dlenia }\end{array}$ & $\begin{array}{c}\text { reforma } \\
\text { WESA }\end{array}$ \\
\hline Camera Deputaților (RO1) & 5 & 7 & 1 & 5 & 6 & 12 \\
\hline Poslanecká sněmovna (CZ1) & 3 & 7 & 1 & 6 & 4 & 13 \\
\hline Sénat (CZ2) & 4 & 7 & 1 & 5 & 5 & 12 \\
\hline Senato della Repubblica (IT2) & 3 & 7 & 2 & 5 & 5 & 12 \\
\hline Assembleia da República (PT) & 1 & 7 & 0 & 6 & 1 & 13 \\
\hline Bundesrat (DE2) & 1 & 5 & 1 & 4 & 2 & 9 \\
\hline Senatul (RO2) & 3 & 4 & 1 & 4 & 4 & 8 \\
\hline Camera dei Deputati (IT1) & 4 & 3 & 2 & 3 & 6 & 6 \\
\hline Senat (PL2) & 1 & 2 & 1 & 1 & 2 & 3 \\
\hline Cortes Generales (ES) & 2 & 0 & 2 & 0 & 4 & 0 \\
\hline Národná Rada (SK) & 2 & 1 & 0 & 0 & 2 & 1 \\
\hline Sejm (PL1) & 0 & 1 & 1 & 0 & 1 & 1 \\
\hline Vouli ton Antiprosopon (CY) & 1 & 0 & 1 & 0 & 2 & 0 \\
\hline Országgyúlés (HU) & 0 & 1 & 0 & 0 & 0 & 1 \\
\hline \hline
\end{tabular}

Źródło: Opracowanie własne (Annual statistics; National Parliament opinions).

Podsumowanie opinii przesyłanych przez parlamenty krajowe w ramach dialogu politycznego z KE i wymiany opinii z PE pokazuje także, że z tej formy oddziaływania na kształt ustawodawstwa unijnego korzystały chętniej państwa, które nie sprzeciwiały się zarówno mechanizmowi relokacji i przesiedleń, jak i reformie WESA (National Parliament opinions). W opiniach dotyczących projektu rozporządzenia ustanawiającego stały mechanizm relokacji z 9 września 2015 r. cypryjski Vouli ton Antiprosopon poparł propozycję KE i wyraził potrzebę podjęcia szybkich działań opartych o solidarność i podział odpowiedzialności między państwa członkowskie. Niemiecki Bundesrat oraz włoska Camera dei Deputati w swojej opinii wysłanej do PE i KE również poparły stały mechanizm relokacji. Hiszpańskie Cortes Generales podkreśli- 
ły, że proponowane ustanowienie listy krajów bezpiecznych nie stoi w sprzeczności z prawami podstawowymi. Wskazały jednocześnie, że stały mechanizm relokacji zaproponowany przez KE 9 września 2015 r. powinien być traktowany jako jednostkowe działanie w sytuacji kryzysowej, ale nie może zastąpić utworzenia wspólnotowej polityki migracyjnej, azylowej i kontroli granic.

\section{Podsumowanie}

Zaangażowanie parlamentów państw członkowskich w latach 2015-2017 w działania na rzecz przezwyciężenia kryzysu migracyjnego w UE koncentrowało się wokół wykorzystywania kilku narzędzi politycznych i instytucjonalnych, w które krajowe legislatury wyposażył traktat lizboński. Spośród pięciu wyodrębnionych instrumentów, parlamenty skorzystały z czterech. Były to: prawo do otrzymywania informacji o dokumentach legislacyjnych i nielegislacyjnych, opiniowanie ich pod kątem zgodności z zasadą subsydiarności, prowadzenie pisemnego dialogu politycznego z KE, a także wymiana opinii w ramach kontaktów międzyparlamentarnych. Ze względu na brak odpowiednich regulacji wykonawczych w analizowanym okresie, parlamenty nie skorzystały z instrumentu, jakimi jest ocena i kontrola przestrzeni wolności, bezpieczeństwa i sprawiedliwości w tych aspektach, które odnosiły ją do polityki migracyjnej, azylowej i kontroli granic.

Nie wszystkie formy współpracy międzyparlamentarnej dawały okazję parlamentom do prezentowania swoich indywidualnych stanowisk w odniesieniu do projektów legislacyjnych dotyczących relokacji i przesiedleń oraz reformy WESA. Prace na wysokim szczeblu politycznym przewodniczących parlamentów krajowych w ramach KPPUE prowadzone są co do zasady w oparciu o konsensus. Na tej podstawie przyjmowane są konkluzje końcowe tego gremium. O ile pierwsze $\mathrm{z}$ analizowanych $\mathrm{w}$ artykule spotkań KPPUE w kwietniu 2015 r. charakteryzowało się zgodnym stanowiskiem wobec komunikatu KE pt. Europejski program w zakresie migracji, o tyle w czasie kolejnego spotkania w maju 2016 r. uwidoczniła się rozbieżność stanowisk. Swoje zastrzeżenia do tworzenia wspólnego systemu azylowego w oparciu o stały mechanizm relokacji, zaproponowanego przez KE w maju i wrześniu 2015 r., zgłosiło sześć izb parlamentarnych ze Słowacji, Polski, Czech i Węgier.

Stopniowe narastanie wyraźnych różnic między parlamentami wobec propozycji KE, mających na celu zażegnanie kryzysu migracyjnego, widoczne było także w innych gremiach stanowiących narzędzie współpracy międzyparlamentarnej. Pod koniec 2015 r. w badaniach opinii i stanowisk parlamentów w ramach COSAC szesnaście izb parlamentarnych zaprezentowało swoje poglądy na temat środków podjętych przez KE w zakresie polityki migracyjnej i azylowej. Negatywne stanowisko wyraziły izby parlamentarne z Polski, Węgier, Estonii, Czech, Litwy, Łotwy, Słowacji oraz Austrii i Wielkiej Brytanii (w ostatnich dwóch przypadkach tylko jedna izba). Postulowały one rozmieszczanie uchodźców w państwach UE na zasadzie dobrowolności i sprzeciwiły się tzw. kwotom imigracyjnym określonym przez KE dla państw członkowskich, uznając, że KE powinna utworzyć rozsądny systemu podziału oparty na faktycznych możliwościach państw. Pięć izb parlamentów krajowych w ankiecie COSAC poparło 
propozycję KE dotyczącą systemu podziału uchodźców z maja i września 2015 r. Były to portugalska Assembleia da República, włoskie Camera dei deputati i Senato della Repubblica, niemiecki Bundesrat i holenderska Tweede Kamer. Ankieta COSAC posłużyła także parlamentom do przedstawienia nowych rozwiązań, które mogłyby zostać wykorzystane przez KE. Świadczy to, że parlamenty w ramach przysługujących im narzędzi nie tylko wypełniały reaktywną rolę polegającą na jednostronnym odnoszeniu się do tematów, które narzuciła im KE, ale starały się aktywnie kształtować rozwiązania na poziomie unijnym mające na celu zażegnanie kryzysu migracyjnego, dzieląc się własnymi koncepcjami z instytucjami UE. Temu celowi służyły także takie narzędzia instytucjonalne, jak spotkania w ramach Międzyparlamentarnej Konferencji ds. WPZiB/WPBiO oraz międzyparlamentarne spotkanie komisji PE i parlamentów krajowych. Szczególnie to ostatnie gremium, którego spotkanie w dniu 28 lutego 2017 r. stanowiło okazję dla parlamentarzystów z państw członkowskich do tego, aby zaprezentować stanowiska krajowe w kwestii mechanizmów relokacji i przesiedleń oraz funkcjonowania WESA.

Analiza ilościowa i jakościowa pokazała zróżnicowaną aktywność parlamentów, jeżeli chodzi o wykorzystanie narzędzi kontroli przestrzegania zasady subsydiarności i dialogu politycznego. Najwięcej zastrzeżeń dotyczących zgodności z zasadą pomocniczości padało wobec wniosku KE z 9 września 2015 r. dotyczącego ustanowienia kryzysowego mechanizmu relokacji oraz wniosku KE z 4 maja 2016 r. zmieniającego rozporządzenie Dublin III i ustanawiającego tzw. korekcyjny mechanizm przydziału. Łącznie było to trzynaście uzasadnionych opinii. Jednak wykorzystywały je przede wszystkim kraje, które sprzeciwiały się generalnie opracowanym przez KE rozwiązaniom. Czeskie Poslanecká sněmovna i Sénat złożyły łącznie cztery tego typu opinie do KE i PE, węgierski Országgyülés dwie uzasadnione opinie do KE i PE, rumuńska Camera Deputaților dwie uzasadnione opinie do KE i PE, słowacka Národná Rada dwie uzasadnione opinie do KE i PE, polski Sejm i Senat dwie uzasadnione opinie do KE i PE oraz włoski Senato della Republica, który przedłożył jedną uzasadnioną opinię. Wśród parlamentów krajowych najwięcej opinii w ramach dialogu politycznego z KE oraz opinii wysyłanych do PE, a więc w ramach bardziej elastycznych instrumentów niż wcześniej opisane uzasadnione opinie, wysłała rumuńska Camera Deputaților. Zaś parlamenty państw, które nie sprzeciwiały się zarówno mechanizmowi relokacji i przesiedleń, jak i reformie WESA chętniej wykorzystywały dialog polityczny niż narzędzia związane z kontrolą przestrzegania zasady pomocniczości. Były to: cypryjski Vouli ton Antiprosopon, włoska Camera dei Deputati i Assembleia da República, hiszpańskie Cortes Generales oraz niemiecki Bundesrat.

Przeprowadzony w artykule wywód pozwolił zidentyfikować najczęściej używane instrumenty polityczne i instytucjonalne, które mają do dyspozycji parlamenty narodowe. $\mathrm{Z}$ pewnością zakres zaangażowania krajowych legislatury $\mathrm{w}$ działania na rzecz przezwyciężenia kryzysu migracyjnego byłby większy, gdyby w latach 2015-2017 funkcjonowała grupa ds. wspólnej kontroli parlamentarnej, pozwalająca prowadzić kontrolę działań Europolu. Jednocześnie można było zauważyć, że parlamenty narodowe państw negatywnie ustosunkowanych do przyjmowania imigrantów, czyli przede wszystkim państw z Europy Środkowo-Wschodniej, były bardziej aktywne na forum UE niż parlamenty państw pozytywnie nastawionych do migrantów. Te pierwsze wy- 
korzystywały praktycznie każdy z dostępnych instrumentów w UE, aby przedstawić i uzasadnić swoje stanowisko.

\section{Bibliografia}

Adamczyk A. (2016), Kryzys imigracyjny w UE i sposoby jego rozwiązania, „Przegląd Politologiczny", nr 3.

Annex I. Conclusions of the Presidency of the Conference of Speakers of the European Union Parliaments, 23-24 April 2017, "ipex.eu”, http://www.ipex.eu/IPEXL-WEB/dossier/files/download/082dbcc55b9d0bca015ba04285ea0259.do, 25.07.2018.

Annual statistics for subsidiarity checks by national parliaments, "europarl.europa.eu”, http://www. europarl.europa.eu/relnatparl/en/about/subsidiarity.html, 25.07.2018.

Borońska-Hryniewiecka K. (2015), „Zielona kartka”: czas na rewizję zaangażowania parlamentów narodowych w politykę Unii Europejskiej, „Biuletyn Polskiego Instytut Spraw Międzynarodowych", nr 39.

Czachór Z. (2013), Parliamentary dimension of the Polish presidency, „Środkowoeuropejskie Studia Polityczne", nr 3.

Conference of the Speakers of the EU Parliaments (2015), Conclusions of the Presidency, Rome, 20-21 April 2015, “ipex.eu”, http://www.ipex.eu/IPEXL-WEB/dossier/files/download/ 082dbcc54ce35cd0014ce64535e5028a.do, 25.07.2018.

Conference of Speakers of the EU Parliaments (2016), Conclusions of the Presidency, Luxembourg, 22-24 May 2016, “ipex.eu”, http://www.ipex.eu/IPEXL-WEB/dossier/files/download/ 082dbcc5552d18f501552ff39e210253.do, 25.07.2018.

Draft conclusions of the Presidency, Conference of Speakers of the EU Parliaments, Luxembourg, 22-24 May 2016, "ipex.eu”, http://www.ipex.eu/IPEXL-WEB/dossier/files/download/ 082dbcc5533eed600153412c40f10191.do, 25.07.2018.

Dulak M. (2017), Legitymizacja polskiej polityki europejskiej. Analiza systemowa, Wydawnictwo Księgarnia Akademicka, Kraków.

Dwudziesty czwarty raport pótroczny: zmiany stosowanych w Unii Europejskiej procedur i praktyk dotyczacych kontroli parlamentarnej, COSAC, Luksemburg, 29 listopada-1 grudnia 2015, http://oide.sejm.gov.pl/oide/images/files/international/raport_cosac_24.pdf, 25.07.2018.

European Parliament, Summaries of reasoned opinions and contributions of national parliaments on Commission Proposals: COM (2015) 452, COM (2016) 270, COM (2016) 271, COM (2016) 272, COM (2016) 465, COM (2016) 466, COM (2016) 467, COM (2016) 468 , "europarl.europa.eu", http://www.epgencms.europarl.europa.eu/cmsdata/upload/ 14a71383-329f-4fb7-8fac-85e74ba8ad30/Summaries_of reasoned opinions and contributions.pdf, 25.07.2018.

Eurostat, Asylum and first time asylum applicants by citizenship, age and sex. Annual aggregated data, "eurostat.ec.europa.eu", http://appsso.eurostat.ec.europa.eu/nui/show.do?dataset=migr_ asyappctza\&lang=en, 25.07.2018.

Grzelak A., Łacny J. (2011), Kontrola przestrzegania unijnej zasady pomocniczości przez parlamenty narodowe - pierwsze doświadczenia, „Zeszyty Prawnicze Biura Analiz Sejmowych”, nr 4.

Haroche P. (2018), The inter-parliamentary alliance: how national parliaments empowered the European Parliament, "Journal of European Public Policy", vol. 25, issue 7.

Komisja Europejska, Komunikat Komisji do Rady Europejskiej. Plan osiagnięcia wyników dla Europy z myśla o obywatelach, Bruksela, 10 maja 2006, COM (2006) 211.

Komisja Europejska, Wniosek. Rozporzadzenie Parlamentu Europejskiego i Rady w sprawie Agencji Unii Europejskiej ds. Wspótpracy Wymiarów Sprawiedliwości w Sprawach Karnych (Eurojust), Bruksela, 17 lipca 2013, COM (2013) 535 final. 
Komisja Europejska, Komunikat Komisji do Parlamentu Europejskiego, Rady, Europejskiego Komitetu Ekonomiczno-Spolecznego i Komitetu Regionów. Europejski Program w zakresie migracji, Bruksela, 13 maja 2015 r., COM (2015) 240.

Komisja Europejska, Wniosek. Decyzja Rady wprowadzająca środki przejściowe w dziedzinie ochrony międzynarodowej na korzyść Włoch i Grecji, Bruksela, 27 maja 2015 r., COM (2015) 286.

Komisja Europejska, Wniosek. Rozporzadzenie Parlamentu Europejskiego i Rady ustanawiajace kryzysowy mechanizm relokacji $i$ zmieniające rozporządzenie Parlamentu Europejskiego i Rady (UE) nr 604/2013 z dnia 26 czerwca 2013 r. w sprawie ustanowienia kryteriów i mechanizmów ustalania państwa członkowskiego odpowiedzialnego za rozpatrzenie wniosku o udzielenie ochrony międzynarodowej złożonego w jednym z państw członkowskich przez obywatela państwa trzeciego lub bezpaństwowca, Bruksela, 9 września 2015 r., COM (2015) 450.

Komisja Europejska, Wniosek. Decyzja Rady wprowadzająca środki tymczasowe w dziedzinie ochrony międzynarodowej na rzecz Włoch, Grecji i Węgier, Bruksela, 9 września 2015 r., COM (2015) 451.

Komisja Europejska, Wniosek. Rozporzadzenie Parlamentu Europejskiego i Rady ustanawiajace unijny wspólny wykaz bezpiecznych krajów pochodzenia do celów dyrektywy Parlamentu Europejskiego $i$ Rady 2013/32/UE w sprawie wspólnych procedur udzielania i cofania ochrony międzynarodowej, oraz zmieniajace dyrektywę 2013/32/UE. Bruksela, 9 września 2015 r., COM (2015) 452.

Komisja Europejska, Komunikat Komisji do Parlamentu Europejskiego i Rady. Plan działania UE w zakresie powrotów, Bruksela, 9 września 2015 r., COM (2015) 453.

Komisja Europejska, Komunikat Komisji do Parlamentu Europejskiego i Rady. W Kierunku Reformy Wspólnego Europejskiego Systemu Azylowego i Zwiększenia Liczby Legalnych Sposobów Migracji do Europy, Bruksela, 6 kwietnia 2016 r., COM (2016) 197.

Komisja Europejska, Wniosek. Rozporzadzenie Parlamentu Europejskiego i Rady w sprawie ustanowienia kryteriów i mechanizmów ustalania państwa członkowskiego odpowiedzialnego za rozpatrzenie wniosku o udzielenie ochrony międzynarodowej złożonego w jednym z państw czlonkowskich przez obywatela państwa trzeciego lub bezpaństwowca (wersja przekształcona), Bruksela, 4 maja 2016 r., COM (2016) 270.

Komisja Europejska, Wniosek. Rozporzadzenie Parlamentu Europejskiego i Rady w sprawie Agencji Unii Europejskiej ds. Azylu i uchylajace rozporządzenie (UE) nr 439/2010, Bruksela, 4 maja 2016 r., COM (2016) 271.

Komisja Europejska, Wniosek. Rozporzadzenie Parlamentu Europejskiego i Rady w sprawie ustanowienia systemu EURODAC do porównywania odcisków palców w celu skutecznego stosowania [rozporzadzenia (UE) nr 604/2013 w sprawie ustanowienia kryteriów i mechanizmów ustalania państwa członkowskiego odpowiedzialnego za rozpatrzenie wniosku o udzielenie ochrony międzynarodowej złożonego $w$ jednym z państw członkowskich przez obywatela państwa trzeciego lub bezpaństwowca] na potrzeby identyfikowania nielegalnie przebywajacy obywateli państw trzecich lub bezpaństwowców oraz $w$ sprawie występowania o porównanie z danymi EURODAC przez organy ścigania państw członkowskich i Europol na potrzeby ochrony porządku publicznego (wersja przekształcona), Bruksela, 4 maja 2016 r., COM (2016) 272.

Komisja Europejska, Wniosek. Dyrektywa Parlamentu Europejskiego i Rady w sprawie ustanowienia norm dotyczacych przyjmowania osób ubiegających się o ochronę międzynarodowa (wersja przekształcona), Bruksela, 13 lipca 2016 r., COM (2016) 465.

Komisja Europejska, Wniosek. Rozporzadzenie Parlamentu Europejskiego i Rady w sprawie norm dotyczacych kwalifikowania obywateli państw trzecich lub bezpaństwowców jako osób korzystających z ochrony międzynarodowej, jednolitego statusu uchodźców lub osób kwalifi- 
kujacych się do otrzymania ochrony uzupetniajacej oraz zakresu udzielanej ochrony oraz zmieniające dyrektywę Rady 2003/109/WE z dnia 25 listopada 2003 r. dotyczaca statusu obywateli państw trzecich będących rezydentami dtugoterminowymi, Bruksela, 13 lipca 2016 r., COM (2016) 466.

Komisja Europejska, Wniosek. Rozporzadzenie Parlamentu Europejskiego i Rady ustanawiajace wspólna procedurę ubiegania się o ochronę międzynarodowa w Unii i uchylajace dyrektywę 2013/32/UE, Bruksela, 13 lipca 2016 r., COM (2016) 467.

Komisja Europejska, Wniosek. Rozporzadzenie Parlamentu Europejskiego i Rady ustanawiajace unijne ramy przesiedleń i zmieniające rozporzadzenie Parlamentu Europejskiego $i$ Rady (UE) nr 516/2014, Bruksela, 13 lipca 2016 r., COM (2016) 468.

Komisja Europejska, Załacznik do Sprawozdania Komisji. Sprawozdanie roczne za rok 2015 w sprawie pomocniczości i proporcjonalności, Bruksela, 15 lipca 2016 r., COM (2016) 469 final.

Komisja Europejska, Załaczniki do sprawozdania Komisji. Sprawozdanie roczne za rok 2015 na temat stosunków między Komisją Europejską a parlamentami narodowymi, Bruksela, 15 lipca 2016r., COM (2016) 471 final

Komisja Europejska, Załacznik do Sprawozdania Komisji. Sprawozdanie roczne za rok 2016 w sprawie pomocniczości i proporcjonalności, Bruksela, 30 czerwca 2017 r., COM (2017) 600 final.

Komisja Europejska, Załaczniki do sprawozdania Komisji. Sprawozdanie roczne za rok 2016 na temat stosunków między Komisją Europejską a parlamentami narodowymi, Bruksela, 30 czerwca 2017 r., COM (2017) 601 final.

Konferencja międzyparlamentarna ds. wspólnej polityki zagranicznej i bezpieczeństwa oraz wspólnej polityki bezpieczeństwa i obrony, (2015a), Końcowe konkluzje, Ryga, 4-6 marca 2015 r., „oide.sejm.gov.pl”, http://oide.sejm.gov.pl/oide/images/files/international/WPZiB_WPBiO/ cfsp_csdp_konkluzje_03_2015_pl.pdf, 25.07.2018.

Konferencja międzyparlamentarna ds. Wspólnej polityki zagranicznej i bezpieczeństwa oraz wspólnej polityki bezpieczeństwa i obrony (2015b), Wnioski końcowe, Luksemburg, 5-6 września 2015 r., ,oide.sejm.gov.pl”, http://oide.sejm.gov.pl/oide/images/files/international/WPZiB_ WPBiO/cfsp_csdp_konkluzje_09_2015pl.pdf, 25.07.2018.

Konferencja międzyparlamentarna ds. Wspólnej polityki zagranicznej i bezpieczeństwa oraz wspólnej polityki bezpieczeństwa i obrony (2016a), Konkluzje końcowe, Haga, 6-8 kwietnia 2016 r., „oide.sejm.gov.pl”, http://oide.sejm.gov.pl/oide/images/files/international/WPZiB_ WPBiO/cfsp_csdp_konkluzje_04_2016_pl.pdf, 25.07.2018.

Konferencja międzyparlamentarna ds. Wspólnej polityki zagranicznej i bezpieczeństwa oraz wspólnej polityki bezpieczeństwa i obrony (2016b), Wnioski końcowe, Bratysława, 2-4 września 2016 r., „oide.sejm.gov.pl”, http://oide.sejm.gov.pl/oide/images/files/international/WPZiB_ WPBiO/cfsp_csdp_konkluzje_09_2016_pl.pdf, 25.07.2018.

Konferencja międzyparlamentarna ds. Wspólnej polityki zagranicznej i bezpieczeństwa oraz wspólnej polityki bezpieczeństwa i obrony (2017), Wnioski końcowe, Malta, 26-28 kwietnia 2017 r., „oide.sejm.gov.pl”, http://oide.sejm.gov.pl/oide/images/files/international/WPZiB_ WPBiO/cfsp_csdp_konkluzje_04_2017_pl.pdf, 25.07.2018.

Leksykon wielostronnej wspótpracy parlamentarnej w sprawach UE, ,oide.sejm.gov.pl” http://oide. sejm.gov.pl/oide/index.php?option=com_content\&view=article\&id=14738\&Itemid=774, 25.07.2018.

Mik C. (2010), Pozycja prawna parlamentów narodowych w Unii Europejskiej w świetle Traktatu $z$ Lizbony, „Ruch Prawniczy, Ekonomiczny i Socjologiczny”, z. 2.

National Parliament opinions and Commission replies, "ec.europa.eu", http://ec.europa.eu/dgs/ secretariat_general/relations/relations_other/npo/index_en.htm, 25.07.2018.

Protokót nr 1 w sprawie roli parlamentów narodowych w Unii Europejskiej, w: Wersje skonsolidowane Traktatu o Unii Europejskiej i Traktatu o funkcjonowaniu Unii Europejskiej, Dz. Urz. UE C 202 z 7 czerwca 2016 r. 
Protokót $n r 2 w$ sprawie stosowania zasady pomocniczości i proporcjonalności, w: Wersje skonsolidowane Traktatu o Unii Europejskiej $i$ Traktatu o funkcjonowaniu Unii Europejskiej, Dz. Urz. UE C 202 z 7 czerwca 2016 r.

Pudło A. (2014), Rola parlamentu narodowego w sprawach UE po wejściu w życie Traktatu z Lizbo$n y$, Dom wydawniczy ELIPSA, Warszawa.

Reasoned opinions on COM/2015/0450, “ipex.eu”, http://www.ipex.eu/IPEXL-WEB/dossier/document/COM20150450.do\#dossier-COD20150208, 25.07.2018.

Reasoned opinions on COM/2016/0270, “ipex.eu”, http://www.ipex.eu/IPEXL-WEB/dossier/document/COM20160270.do\#dossier-COD20160133, 25.07.2018.

Relations with national parliaments (WWW), “europarl.europa.eu”, http://www.europarl.europa.eu/ relnatparl/en/meetings.html, 25.07.2018.

Rozporzadzenie Parlamentu Europejskiego i Rady (UE) 2016/794 z dnia 11 maja 2016 r. w sprawie Agencji Unii Europejskiej ds. Wspótpracy Organów Ścigania (Europol), zastępujące i uchylajace decyzje Rady 2009/371/WSiSW, 2009/934/WSiSW, 2009/935/WSiSW, 2009/936/ WSiSW i 2009/968/WSiSW, Dz. Urz. UE 2016 L 135.

Rozporzadzenie Parlamentu Europejskiego i Rady (UE) 2018/1727 z dnia 14 listopada 2018 r. w sprawie Agencji Unii Europejskiej ds. Wspótpracy Wymiarów Sprawiedliwości w Sprawach Karnych (Eurojust) oraz zastapienia i uchylenia decyzji Rady 2002/187/WSiSW, Dz. U. L 295 z 21.11.2018.

Rules of procedure of the joint parliamentary scrutiny group on Europol, Sofia, 19 March 2018, "oide.sejm.gov.pl", http://oide.sejm.gov.pl/oide/en/images/files/international/INNE/rules_ jpsg.pdf, 25.07.2018.

The Third Reform of the Common European Asylum System - Up for the Challenge, "europarl.europa.eu", 28 February 2017, http://www.europarl.europa.eu/committees/p1/libe/events-nationalparl.html?id=20170208MNP00041, 25.07.2018.

Traktat o Unii Europejskiej (wersja skonsolidowana), Dz. Urz. UE C 202/1 z 7 czerwca 2016 r.

Traktat o funkcjonowaniu Unii Europejskiej (wersja skonsolidowana), Dz. Urz. UE. C 202/1 z 7 czerwca $2016 \mathrm{r}$.

UNHCR Operational portal. Refugee situations, “unhcr.org”, https://data2.unhcr.org/en/situations/ mediterranean, 25.07.2018.

Węc J. J. (2008), The Influence of National Parliaments on the Decision-making Process in the European Union. New Challenges in the Light of the Lisbon Treaty, "Politeja", no. 2/1 (10/1).

Węc J. J (2011), Traktat lizboński. Polityczne aspekty reformy ustrojowej Unii Europejskiej w latach 2007-2009, Wydawnictwo Księgarnia Akademicka, Kraków.

Węc J. J. (2017), Reforma polityki imigracyjnej, kontroli granic zewnętrznych oraz polityki azylowej Unii Europejskiej w dobie kryzysu migracyjnego (2015-2016), „Przegląd Zachodni”, nr 2.

Witkowska M. (2016), The use of the concept of policy networks in the study of relations between national parliaments and the EU institutions, ,Przegląd Europejski”, nr 4(42).

\section{Streszczenie}

Zaangażowanie parlamentów państw członkowskich w dyskusję nad problemem nielegalnej migracji do UE przybrało na sile w latach 2015 i 2016. Artykuł omawia uprawnienia przysługujące parlamentom na mocy traktatu lizbońskiego, pozwalające im wpływać na procesy polityczne w UE, w szczególności w ramach polityki migracyjnej, azylowej i kontroli granic. Następnie przedstawiono aktywność parlamentów w latach 2015-2017 wobec propozycji legislacyjnych KE dotyczących mechanizmu relokacji i przesiedleń oraz reformy wspólnego europejskiego systemu azylowego. 
Uzyskane wnioski pozwalają stwierdzić, że najczęściej używanymi przez parlamenty instrumentami była współpraca międzyparlamentarna, kontrola przestrzegania zasady pomocniczości oraz dialog polityczny. Ze względu na brak niezbędnych aktów wykonawczych pozwalających prowadzić kontrolę działań Europolu, parlamenty w latach 2015-2017 nie wykorzystywały w ogóle spotkań grupy ds. wspólnej kontroli parlamentarnej w ramach przestrzeni wolności, bezpieczeństwa i sprawiedliwości. Jednocześnie można było zauważyć, że parlamenty narodowe państw negatywnie ustosunkowanych do przyjmowania imigrantów, czyli przede wszystkim państw z Europy Środkowo-Wschodniej, były bardziej aktywne na forum UE niż parlamenty państw pozytywnie nastawionych do migrantów.

Słowa kluczowe: parlamenty narodowe, kryzys migracyjny, relokacje i przesiedlenia, WESA

\section{National parliaments' involvement in the activities aimed at overcoming the immigration crisis in the $\mathrm{EU}$ in the years 2015-2017}

\section{Summary}

Involvement of Member States' parliaments in the debate on the problem of illegal migration to the EU has intensified in 2015 and 2016. The article discusses the powers of parliaments under the Treaty of Lisbon, allowing them to influence political processes in the migration, asylum and borders control policies in the EU. Article presents also the activities of parliaments in the years 2015-2017 regarding the legislative proposals on mechanism of relocation and resettlement and the reform of the Common European Asylum System.

The results show that the instruments most frequently used by parliaments were: interparliamentary cooperation, control of compliance with the principle of subsidiarity and political dialogue. Due to the lack of necessary executive acts to control Europol's activities, in 2015-2017 parliaments did not use the meetings of the Europol Joint Parliamentary Scrutiny Group in the area of freedom, security and justice. At the same time, it could be noted that the national parliaments of the Member States that opposed the admission of immigrants (mainly from Central and Eastern Europe) were more active in the EU than the parliaments of states with positive attitude towards relocation and resettlements program.

Key words: national parliaments, migration crisis, relocations and resettlement, CEAS 
